\title{
A UNIVERSIDADE EM RITMO DE BARBÁRIE
}

\section{JOSÉ ARTHUR GIANNOTTI}

São Paulo, Editora Brasiliense, 1986

Mestre Giannotti, com a objetividade que the é peculiar, assume a responsabilidade de decifrar por dentro a Universidade, por além de preconceitos, fórmulas vagas e fáceis, ou palavras de ordem politica.

Analisa sem tréguas os conteúdos corporativos, os populismos, o falso saber. E distingue a ação sindical da ação acadêmica.

Trata-se de um texto frio e duro que não faz qualquer concessão nem aos mandarins nem aos jovens turcos, nem aos democratistas nem aos partidários da autoridade inexplicada.

Sem dúvida, qualquer que seja a postura que se assuma diante do texto, trata-se de importante documento para quem deseja em proveito coletivo, pensar a Universidade e suas estruturas de poder. 